\title{
Społeczność Muzułmanów w Niemczech
}

\begin{abstract}
„Muzutmanie stali się częścią tego społeczeństwa. Ponad trzy miliony muzułmanów żyje w Niemczech na stałe. Oni nie zamierzają wracać do domu. Ich dom jest tutaj".
\end{abstract}

NA D E E E LYA S ${ }^{1}$

C elem niniejszego artykułu jest próba ukazania różnorodności wspólnoty muzułmańskiej w Niemczech. Jak w soczewce można tu obserwować cały wachlarz różnic kulturowych, religijnych i światopoglądowych, spotykanych w świecie islamu. Z jednej strony postrzegać można tą wielorakość jako przejaw bogactwa kulturowego, z drugiej strony w pracach nad wypracowaniem wspólnego stanowiska może ono stanowić barierę.

Emancypacja polityczna organizacji muzułmańskich stanowi ciekawy przejaw tego, w jaki sposób nowe środowisko i panujące w nim reguły mogą wpływać na powstawanie nowych form i zasad organizacji społeczności muzułmańskiej. W przypadku Niemiec, mamy do czynienia obecnie z próbami uspójniania podejść zarówno ze strony rządu niemieckiego, jak i ze strony wspólnot muzułmańskich. Procesowi integracji, towarzyszą gorące debaty dotyczące tożsamości każdej ze stron. Jakie zmiany i przewartościowania dokonały się w społeczeństwie niemieckim, a jakie próbu-

Przewodniczący die Zentralrat der Muslime in Deutschland, cyt za: J. Christopher Soper and Joel Fetzer, Explaining the Accommodation of Muslim Religious Practices in France, Britain, and Germany, Pepperdine University Malibu, CA, 2005, s. 1. 
ją zainicjować poszczególni aktorzy? Co jest najtrudniejsze na obecnym etapie integracji? Co uznawane jest za sukces lub szansę dla dalszego procesu integracji? Niniejsze rozważania stanowią wstęp do rozważań nad tym, na jakim etapie znajduje się społeczność muzułmańska w Niemczech i jakie czynniki wpływają na jej kondycję.

Zróżnicowanie muzułmanów niemieckich pod względem etnicznym, społecznym, jak i religijnym wynika przede wszystkich z imigranckiego pochodzenia przeważającej części jej członków. Z jednej strony są to potomkowie pracowników sezonowych, przybyłych głownie z Turcji, Maroka Tunezji oraz krajów byłej Jugosławii ${ }^{2}$ w okresie powojennego boomu gospodarczego. Z drugiej strony społeczność ta ma swoje źródła w emigracji politycznej i uchodźczej z Autonomii Palestyny/Izraela, Afganistanu, Bośni, Egiptu, Iraku czy Iranu. Wraz z dorastaniem dzieci i odnajdywaniem się w kulturze niemieckiej, pewna część muzułmańskich imigrantów zaczęła starania o potwierdzenie przynależności do nowego kraju, przy zachowaniu jednak swej odrębności kulturowo-religijnej.

Pierwsze organizacje i grupy powstawały zazwyczaj z inspiracji już doświadczonych aktywistów politycznych, importujących tym samym idee, często zakazane w kraju pochodzenia, jak grupy należące do Braci Muzułmanów, których komórki od lat 80. zaczęły powstawać także w Europie. Lokalne grupy działania nawiązywały do idei islamu jako systemu społecznego i jedności wszystkich muzułmanów, szczególnie w środowisku obcym kulturowo, a przez to wrogim. Podstawą działania pomocną muzułmaninowi $\mathrm{w}$ takim otoczeniu były zasady poprawności religijnej (i'tidal) oraz umiarkowania (wasatijja). Czyli dbałość o zachowanie swojej tożsamości kulturowej oraz odrzucenie przemocy i nastawienie na dia$\log ^{3}$. Jednocześnie duża część muzułmanów mieszkających w Niemczech to niepraktykujący muzułmanie kulturowi ${ }^{4}$.

Podobnie jak w innych demokracjach Europy Zachodniej, proces osadzania się islamu w tych społeczeństwach przebiegał niezauważenie dla głównego nurtu spraw, nie przyciągając powszechnej uwagi mediów

Imigranci przybywali do Niemiec na podstawie umów gospodarczych z rządami krajów, podpisanymi w latach 1961-1968. Nabór został wstrzymany w 1972 r. i zezwolono na łączenie rodzin, zob. A. Nalborczyk, Muzułmanie w Niemczech - wielka społeczność religijna nieznana przez państwo, A. Parzymies (red.), Muzułmanie w Europie, Dialog, Warszawa 2005, s. 327.

J. Zdanowski, Współczesna muzułmańska myśl społeczno-polityczna. Nurt Braci Muzułmanów, Askon, Warszawa 2009, s. 101.

4 P. Heine, Halbmond über deutschen Dächern. Muslimen Leben in unserem Land, List Verlag, Monachium 1997, s. 116. 
aż do ataku na World Trade Center (WTC) w 2001 r. Generalnie wzrost zainteresowania europejskimi grupami muzułmańskimi można uznać za wprost proporcjonalny do rosnącego „zagrożenia islamizacją Europy”. Z roku na rok po atakach na WTC, zaczęły pojawiać się doniesienia o radykalizacji muzułmańskich społeczności w Europie, ich sporej liczebności oraz skutkach, jakie to może przynieść Europie ${ }^{5}$. Niemiecka wspólnota stała się w centrum zainteresowania po odkryciu, że Muhammad Atta, kierujący grupą odpowiedzialną za zamach na World Trade Center, studiował i pracował w Hamburgu.

Niemcy, w przeciwieństwie do Francji czy Wielkiej Brytanii, w tak szerokim zakresie z islamem zetknęły się właśnie poprzez nową falę imigracyjną lat 60 . XX wieku'. Brak przeszłości kolonialnej spowodował, że przybysze stali się „skutkiem ubocznym" wzrostu gospodarczego. To powodowało, że prawa obywatelskie i wpływ imigrantów na sytuację polityczną w Niemczech był znikomy, w przeciwieństwie do W. Brytanii czy Francji, dawnych imperiów kolonialnych.

\section{Od imigrantów do obywateli}

Dowodem na dotychczasowy niski poziom wiedzy na temat struktury niemieckiej mniejszości muzułmańskiej są wyniki badań zrealizowanych na zlecenie niemieckiego Ministerstwa Spraw Wewnętrznych, które wykazują, że w Niemczech żyje około 4 milionów muzułmanów (szacuje się, że jest to liczba w przedziale $3,8-4,3$ miliona osób) ${ }^{7}$, a nie jak wcze-

Od zamachów w metrach Madrytu i Londynu można obserwować wzrost liczby artykułów na temat „postępującej islamizacji Europy”, szczególnie sprzyjającymi temu procesowi mają być czynniki demograficzne, czyli wielodzietność rodzin oraz starzenie się społeczeństw europejskich. Por. M. Szymaniak, Chrześcijańskiej Europie grozi islamizacja?, [w:] Rzeczpospolita, 10.01.2010, http://www.rp.pl/artykul/123162,417184. html, (28.09.2010); Charakterystycznym zjawiskiem są demonstracje przeciw islamizacji, czy meczetom, które odbywają się co jakiś czas w krajach europejskich, np. Bruksela: Demonstracja przeciwko ‘islamizacji Europy', w: Gazeta Wyborcza, 11.09.2007, http://forum.gazeta.pl/forum/w,902,68870080,68873152,Bruksela_demonstracja_ przeciwko_islamizacji_E_.html, (28.09.2010).

P. Heine, op. cit., s. 301.

S. Haug, S. Müssig, A. Stichs, Muslimisches Leben in Deutschland im Auftrag der Deutschen Islam Konferenz, Budesamt für Migration und Flüchtlinge, czerwiec 2009, s. 11, dostępny na: http://www.bmi.bund.de/SharedDocs/Downloads/DE/Themen/ Politik_Gesellschaft/DIK/vollversion_studie_muslim_leben_deutschland_.pdf? blob=publicationFile, (28.09.2010). 
śniej powszechnie szacowano 2,8-3 miliony ${ }^{8}$. Jest to pierwsze tak szerokie i dokładne badanie na reprezentatywnej grupie muzułmanów niemieckich, stąd też dowiadujemy się, że połowa muzułmańskiej społeczności ma obywatelstwo niemieckie. Do takiej zmiany w ramach głównie imigranckiej społeczności muzułmanów w Niemczech doszło po nowelizacji ustawy o przyznawaniu obywatelstwa niemieckiego, która weszła w życie w 2000 roku.

Podstawą do zmian na rzecz liberalizacji zasad nadawania obywatelstwa osobom z rodzin imigranckich było przede wszystkim zaobserwowanie paradoksalnej sytuacji, gdzie imigrantami były głównie osoby urodzone i wychowane w Niemczech. W związku z tym przyjęto zasadę „ius soli” („prawo ziemi”), dzięki której dzieci imigrantów, urodzonych w Niemczech po 2000 roku automatycznie nabywają obywatelstwo niemieckie. Tą samą zasadę stosuje się względem dzieci imigranckich, urodzonych przed 2000 rokiem, ale które nie ukończyły 10 roku życia. Natomiast dorośli mogą starać się o obywatelstwo, jeśli mieszkają w Niemczech przez 8 lat (nie jak do tej pory 15 lat), w oparciu o test znajomości zasad współżycia społecznego i zasad demokracji oraz języka niemieckiego ${ }^{9}$. Od 2008 roku test jest dostępny w wersji on-line na stronie ministerstwa. Ukazuje to jak ważna jest integracja lingwistyczna w niemieckiej polityce integracyjnej, co wpływa niejako na podejście do edukacji w szkołach na terenie Niemiec. Z takim podejściem nie zgodził się ostatnio premier Turcji, który podczas wizyty w Niemczech, zwrócił uwagę na powstawanie niemieckich szkół i uniwersytetów w Turcji. Zaproponował podobną praktykę w Niemczech odnośnie mieszkańców tureckiego pochodzenia, co nie spotkało się jednak z przychylnym przyjęciem ze strony niemieckiej administracji ${ }^{10}$.

Raport Ministerstwa wykazuje także, że integracja społeczna muzułmanów z grupami i „sieciami” niemieckimi niemuzułmańskimi jest wyższa niż zazwyczaj zakładano, także w rozmaitych politykach integracyjnych państwa. Ponad połowa muzułmanów po 16 roku życia przynależy do niemieckich stowarzyszeń czy związków, podczas gdy tylko 4 procent badanych z tej grupy ma członkostwo w sieci lub grupie związanej z kra-

Taka liczba była powszechnie uznawana za najbardziej prawdopodobna do 2009 roku. Por. A. S. Nalborczyk, op. cit., s. 333.

9 Das Gesetz zur Reform des Staatsangehörigkeitsrechts vom 15. Juli 1999, Bundesministerium des Innern, http://www.bmi.bund.de, (28.09.2010).

10 Turecki premier chce tureckich szkót w Niemczech, [w:] Gazeta Wyborcza, 26.03.2010, http://wyborcza.pl/1,75477,7702254,Turecki_premier_chce_tureckich_szkol_w_ Niemczech.html, (27.09.2010). 
jem pochodzenia rodziców. Ważnym wskaźnikiem zmiany w kierunku otwartości jest udział większości dziewcząt i chłopców z muzułmańskich rodzin w koedukacyjnych zajęciach sportowych i pływackich ${ }^{11}$. Jörn Thielmann zwraca uwagę, że te wyniki wskazują na słabość dość powszechnej tezy o mocnej korelacji pomiędzy integracją społeczną a wyznawaniem islamu. Omawiane wyniki badań wskazują raczej na trudności w integracji lingwistycznej i strukturalnej niż społecznej, co potwierdzają lepsze wyniki w nauce uczniów z muzułmańskich, lecz nietureckich rodzin. Natomiast słabsze wyniki w nauce dzieci z rodziny z tureckim pochodzeniem powiązać należałoby raczej z niskim zazwyczaj wykształceniem rodziców $\mathrm{i}$ ich statusem społecznym niż z wyznawaną religią ${ }^{12}$.

\section{Różnorodność w jedności}

Jak stwierdza Peter Heine, badacz niemieckiej społeczności muzułmanów, islam nie jest monolitem i „różnice pomiędzy grupami z Pakistanu, Północnej Afryki, Indonezji, Belize, Senegalu czy Turcji są tak znaczne, że uważny obserwator mógłby zadać pytanie, jak długo można mówić o jednym islamie i może bardziej prawdziwą formą w tej sytuacji byłaby zmiana na formę mnogą: islamy" ${ }^{\text {"13 }}$ W ten sposób na świat islamu spoglądać może często zachodni badacz, na co zwraca uwagę prof. M. M. Dziekan rozważając powody posługiwania się takim tworem, jak wspólnota i jedność muzułmańska. Zauważa on, że dostrzeganie różnorodności muzułmańskiej nie powinno przesłaniać faktu postrzegania się przez muzułmanów jako wspólnoty (ummy), połączonej silną więzią islamu. Siła tego wyobrażenia jest tak spójna dla tak wielu muzułmanów na całym świecie, że trudno jej odmówić prawa istnienia i czyni zasadnym posługiwanie się nią w rozważaniach badacza, jak stwierdza Dziekan, odwołując się do idei „wspólnot wyobrażonych” B. Andersena ${ }^{14}$. Wspólnota i różnorodność są szczególnie istotnymi zagadnieniami w kontekście społeczności muzuł-

11 S. Haug, S. Müssig, A. Stichs, op. cit., s. 16.

12 J. Thielmann, The Turkish Bias and Some Blind Spot: Research Muslims in Germany, A. Kreienbrink, M. Bodenstein (red.), Muslim Organization and the State-European Perspective, Bundesamt für Migration und Flüchtlige, styczeń 2010, s. 179.

P. Heine, op. cit., s. 299.

14 Por. M. M. Dziekan, Cywilizacja islamu w Azji i Afryce, Książka i Wiedza, Warszawa 2007, s. 13, propozycję stosowanie liczby mnogiej przez europejskich badaczy rozważa w swoim artykule prof. Anna Parzymies, stwierdzając, że „odmienne jest tu podejście do problemu - z jednej strony mamy podejście teologiczne, muzułmańskie, z drugiej zaś racjonalne, pochodzące z zewnątrz". A. Parzymies (red.), op. cit., s. 20. 
manów w Niemczech ze względu na proces instytucjonalizacji po trosze wymuszony przez wymóg posiadania oficjalnego reprezentanta wspólnoty w prawie wyznaniowym niemieckim, aby stać się podmiotem i partnerem $w$ rozmowach $z$ rządem.

W Niemczech szczególną rolę odgrywają muzułmanie pochodzenia tureckiego. Można wręcz mówić o tureckiej twarzy islamu niemieckiego. Nie świadczy to jednak o jednolitości nawet tej części społeczności, ponieważ jej imigranckie korzenie przejawiają się m.in. w istnieniu wielu podziałów etniczno-religijnych charakterystycznych dla współczesnej Turcji i w ogóle świata islamu. Wśród organizacji i grup niemieckich muzułmanów odnajdziemy, zarówno laicko-tureckie tendencje, polityczny islam z całym jego spektrum ${ }^{15}$, jak i sufickie ugrupowania z całym bogactwem i tajemniczością charakterystycznymi dla tych bractw. Tymczasem prawo wyznaniowe w Niemczech wymusza niejako starania o instytucjonalizację religii, także islamu, który tradycyjnie nie posiada instytucji zarządzającej wiernymi, na wzór kościoła katolickiego.

Islam, poprzez swój silnie podkreślany monoteizm (arab. tawhid), stawia człowieka przed jedynym Bogiem, który nie ma żadnych „wspólników" w swym dziele. Wraz ze śmiercią Muhammada, zakończony został ciąg proroków przekazujących ludziom słowo Boga, ostatecznie zapisanego w sposób doskonały ${ }^{16}$ w Koranie. Wykładnia oraz interpretacja Koranu oraz Sunny (historie z życia Muhammada zebrane przez potomnych) zależą w dużej mierze od kraju pochodzenia, grupy etnicznej i społecznej wiernego. Choć oficjalnie to on osobiście dokonuje własnych decyzji życiowych, powszechnym jest jednak korzystanie z tzw. opinii prawnych (arab. fatw), które mogą zalecać jakieś działanie lub zaniechanie. Fatwa nie jest jednak obowiązująca dla całej wspólnoty jednocześnie. Muzułmanin może de facto dokonać samodzielnego wyboru ze spektrum, którym nazwać można islam za Hasanem Hanafi. Według niego spektrum „oznacza wariacje, pluralizm, różnorodność, ujęcia, oblicza, strony i punkty widzenia

15 Przykładowa typologia dla sunnickiej myśli muzułmańskiej, będącej odpowiedzią na wyzwania współczesności, wyróżnia trzy orientacje ideologiczne: tradycyjną (np. Talibowie), islamistyczną (od reformistów do fundamentalistów) oraz sekularną (kemaliści tureccy), Zob. S. William., The Diversity of Islamic Thought, Suha Taji-Farouki, Basheer M. Nafi (red.), Islamic Thought in the Twentieth Century, I. B. Tauris, Nowy Jork 2004, s. 64.

16 Doskonałość Koranu i wiara, że jest to słowo Boga, nie do poprawienia przez człowieka, stanowi jeden z dogmatów wiary charakterystyczny dla wszystkich odłamów. Taka pozycja zapisów koranicznych, będących źródłem prawa i zasad społecznych stanowi dla niektórych przyczynę problemów z radykalizmem w islamie. 
olbrzymiego pejzażu. Spektrum jednakże ma jeden punkt ogniskowy, jeden środek i jedno łączenie" ${ }^{17}$. Zgodnie z takim podejściem, nie ma jednego islamu i muzułmańską myśl tworzy zarówno lewica jak i prawica Braci Muzułmanów, umiarkowani sunnici żyjący w społeczeństwie zachodnim czy szyici z Iranu. Natomiast fundamentalistami mogą okazać się zarówno radykalni sekularyści i zwolennicy laicyzacji, jak i naśladowcy Ala Maududiego i Sajida Kutba. Podejście H. Hanafiego, oraz równie znanego ze swej oryginalnej myśli Nasra Hamida Abu Zajda, pozwala dostrzec pozorność sprzeczności pomiędzy jednością ummy a jej różnorodnością. Mechanizmami obecnymi we współczesnych dyskursach muzułmańskich, którym sprzeciwiają się ci dwaj uczeni, jest "monolityzacja islamu”, wywodząca się z przekonania o islamie jako monolicie oraz "dogmatyzacji prawd" czyli tworzenia ,jedynych/słusznych" reinterpretacji islamu, wypowiadanych przez samozwańczych przywódców i podchwytywanych przez sfrustrowany tłum. Te metody oraz sprowadzanie wszystkiego do ,jednej podstawy, którą jest Bóg" stanowią próby monopolizacji w rozumieniu islamu i przewodnictwu w ummie ${ }^{18}$. Zarówno spektrum, jak i wymienione metody prowadzenia dyskursu są obecne w całej swej rozciągłości także w Niemczech i szczególnie mocno objawiają się przy próbach utworzenia jednego przedstawiciela dla całej społeczności muzułmanów niemieckich.

\section{Oblicza instytucjonalizacji islamu w Niemczech}

Od początku lat 80., wraz z dorastającym drugim pokoleniem muzułmańskich imigrantów wyedukowanych w niemieckich szkołach, wzmacniały się tendencje do zadbania o swoje interesy jako grupy. Dążenie do oficjalnego uznania wspólnoty muzułmanów przez państwo, stało się de facto dążeniem do uznania oficjalnie za „Körperschaften des öffentlichen Rechts" czyli za osobę prawną prawa publicznego. Dzięki tej regulacji wśród wspólnot religijnych żydów, katolików i protestantów pobierany jest tzw. podatek kościelny, przeznaczany przez państwo na rozwój infrastruktury religijnej danej wspólnoty, zapewniona jest opieka religijna nad członkami tych wspólnot w wojsku, w szkołach i w szpitalach ${ }^{19}$.

17 H. Hanafi, Różnorodność islamu w ujęciu historycznym. Czy islam ma jedno oblicze?, [w:] Bliski Wschód, 2005, nr 2, s. 7.

${ }_{18}$ I. Szybilska, Mechanizmy dyskursu muzułmańskiego a problem władzy w 'Krytyce dyskursu muzułmańskiego' Nasra Hamida Abu Zajda, M. M. Dziekan, I. Kończak (red.), ArabowieIslam-Swiat, Ibidem, Łódź 2007, s. 486.

19 P. Heine, op. cit., s. 114-115. 
W związku z jednym z głównych wymogów, polegającym na wskazaniu reprezentanta całej wspólnoty (osoby lub organizacji) do kontaktów z państwem, muzułmanie starali się stworzyć struktury mogące być takim partnerem do rozmów dla rządu ${ }^{20}$.

Rosnąca świadomość potrzeby posiadania politycznych przedstawicieli doprowadziła do powstawania ruchu, mającego na celu większą spójność działań oraz powołanie do życia muzułmańskiego reprezentanta tzw. organizacji wiodącej (niem. Spitzenverbände), która miała być partnerem do rozmów z rządem. Jako pierwsza w 1978r. o miano reprezentanta zaczął się ubiegać Verband der Islamischen Kulturzentren (VIKZ), jednak te starania nie spotkały się z poparciem wszystkich organizacji muzułmańskich. Podobnie stało się z później powstałą Islamrat für die Budesrepublik Deutschland (Islamrat) ${ }^{21}$. Głównymi przyczynami była reprezentowanie przez obydwie struktury głównie tureckich grup muzułmańskich. W 1994 roku została utworzona Der Zentralrat der Muslime in Deutschland (Zentralrat), bardziej otwarta na inne grupy. Równolegle od 1982 roku działa organizacja zrzeszająca Turkisch-Islamische Union der Anstalt fur Religion e.V. (tur. Dİi̇B - Diyanet İşleri Türk İslam Birliği), skupiająca głównie organizacje tureckiego islamu państwowego, powiązana ściśle z tureckim Prezydium do spraw Religii (tur. Diyanet Isleri Bakanligi/ DIB). Ze względu na spory zasięg działania, mająca pod opieką większość meczetów w Niemczech, pomimo braku statusu organizacji wiodącej, jest ważnym partnerem w rozmowach na temat oficjalnego uznania islamu.

W wyniku tej potrzeby instytucjonalizacji wśród społeczności religijnych, w Niemczech powstały struktury nieznane w krajach tradycyjnie muzułmańskich, jak związek/stowarzyszenie (Vereine), zjednoczenie stowarzyszeń (Vereinigungen), organizacji zwierzchnie/centrale (Dachverbände) oraz wspomniane już organizacje wiodące (Spitzenverbände) ${ }^{22}$. Każda z wymienionych form powinna wchodzić w skład organizacji wyższego stopnia niczym w rosyjskiej matrioszce. Zasada ta jednak nie działa w pełni, z powodu istnienia dwóch konkurujących Spitzenverbände, siły politycznej DITiB, wreszcie braku przejrzystości organizacji, które często nazywają się bardzo podobnie, jak np. liczne Centra Islamskie (Islamische Zentrum), reprezentujące tak naprawdę różne grupy i trendy w islamie ${ }^{23}$.

\footnotetext{
A. S. Nalborczyk, op. cit., s. 338.

Ibidem, s. 339.

U. Spuler-Stegemann, Muslime in Deutschland: Nebeneinande oder Miteinander, Freiburg 1998, s. 101.

23 Ibidem, s. 106.
} 
Starania o stworzenie platformy, która mogłaby się stać się reprezentantem całej wspólnoty, wszedł w nową fazę wraz z utworzeniem w 2007 roku Koordinationsrat der Muslime in Deutschland (KRM). KRM powstało z inicjatywy wymienionych już czołowych organizacji: DITIB, Zentralrat, Islamrat oraz VIKZ. Moment ogłoszenia powstania KRM został przez przewodniczącego Islamrat - Alego Kizilkaya - określony „historycznym dniem dla muzułmanów w Niemczech", którzy nie są już imigrantami i cudzoziemcami, ale „częścią Niemiec” ${ }^{24}$. Z drugiej strony raport ministerstwa wyraźnie mówi, że zaledwie 10\% respondentów kojarzy tę strukturę (najsłabiej z wszystkich wymienionych) ${ }^{25}$.

Wydaje się, że inicjatywa przedwcześnie została tak pozytywnie oceniona przez jej twórców, ponieważ KRM nie jest samodzielną strukturą, która może prowadzić suwerenną politykę i rozmowy z rządem, o czym świadczy też jej brak udziału w pracach w muzułmańsko-rządowym forum - Deutsche Islam Konferenz (DIK) ${ }^{26}$. W drugiej fazie prac DIK, które rozpoczęły się w maju 2010r., biorą natomiast udział następujące organizacje zwierzchnie i wiodące:

- Türkisch-Islamische Union der Anstalt für Religion e. V. (DiTiB)

- Verband Islamischer Kulturzentren e. V. (VIKZ)

- Alevitische Gemeinde Deutschland e. V. (AABF)

- Islamische Gemeinschaft der Bosniaken in Deutschland e. V. (IGBD)

- Zentralrat der Marokkaner in Deutschland e. V.

- Türkische Gemeinde Deutschland (TGD)

Ta ostatnia jest sekularystyczną organizacją imigrancką i została zaproszona do tego grona, aby zapewnić jak największą reprezentatywność strony muzułmańskiej, także kulturowych muzułmanów ${ }^{27}$. Z prac DIK po pierwszej fazie wycofała się jedna z organizacji wiodących - Islamrat. Powodem jej rezygnacji było wykluczenie z prac jej czołowej organizacji członkowskiej Islamische Gemeinschaft Milli Görüş (IGMG), z powodu procesu wytoczonego sekretarzowi generalnemu IGMG - Oğuz

${ }^{24}$ S. Wilms, Y. Alder, Der Prophet verbindet die Muslime, w: Islamischen Zeitungen. Berliner Seiten, kwiecień 2007 (II), s. 13.

25 S. Haug, S. Müssig, op. cit., s. 17.

${ }^{26}$ Informacje na temat Deutsche Islam Konfernz na stronie oficjalnej forum: http:// www.deutsche-islam-konferenz.de.

${ }^{27}$ Neue Teilnehmer des DIK-Plenums, Deutsche Islam Konferenz, 18.05.2010, http://www. deutsche-islam-konferenz.de/cln_110/nn_1875568/SubSites/DIK/DE/DieDIK/ NeueTeilnehmer/neue-teilnehmer-node.html?__nnn=true, (29.09.2010). 
Üçüncü ${ }^{28}$. Druga organizacja wiodąca - Zentralrat jest reprezentowana w tym gremium przez swoją najaktywniejszą organizację członkowską VIKZ. Oczywiście oprócz reprezentantów instytucjonalnych w pracach DIK biorą udział osoby indywidualne, zaangażowane w badania naukowe na temat życia społecznego i religijnego muzułmanów w Niemczech. Ma to pozwolić na elastyczność i jak najszerszy wachlarz różnych poglądów i postaw. Poniższy diagram ukazuje, jak wygląda struktura DIK, zaplanowana tak, aby wypełnić wymóg międzysektorowości, jak i równowagi pomiędzy siłami rządowymi oraz społecznością muzułmańską.

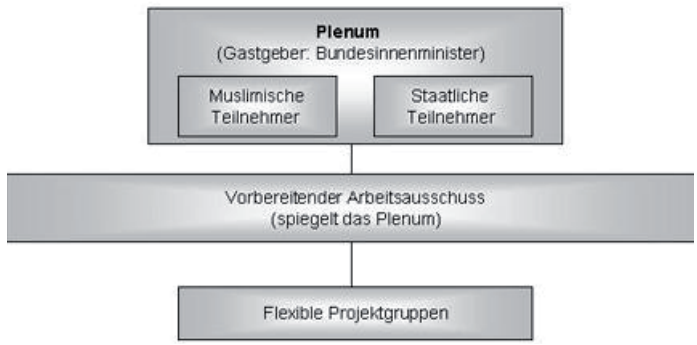

Źródło: oficjalna strona Deutsche Islam Konferenz, 12.05.2010.

Zaangażowanie w tworzenie i koordynowanie DIK osobiście przez Ministra Spraw Wewnętrznych Dr. Thomasa de Maizière wskazuje, że to działania DIK będą wytyczać kierunek rozwoju polityki integracyjnej państwa niemieckiego względem muzułmanów. Jako forum promujące dialog pomiędzy kołami rządowymi a muzułmanami, DIK ma wzmacniać instytucjonalną integrację islamu, społeczną integrację około 4 milionów muzułmanów oraz spójność społeczną w Niemczech. W dotychczasowych pracach osiągnięto, m.in. wspólne rozumienie pojęcia integracji,

28 Werner Schiffauer autor monografii na temat ruchu Milli Görüş, dostrzegł, że doszło do procesu zmiany w ramach grupy; z radykalnych islamistów na grupę nacisku, a sekretarz generalny uznawany może być za post-islamistę. Zob. Susanne Schröter (tłum. Aingeal Flanagan), Werner Schiffauer's Study on the Milli Görüs Movement, Frankfurter Allgemeine Zeitung/Qantara.de 2010, 27.08.2010, http://www.qantara. de/webcom/show_article.php/_c-476/_nr-1384/i.html, (29.09.2010). 
która rozumiana jest jako proces, który zmienia obydwie strony, zarówno społeczeństwo jak i imigrantów. Z jednej strony imigranci powinni wykazać wyższy stopień gotowości do zmian i adaptacji. Z drugiej strony społeczeństwo goszczące wraz z państwem powinni ze swej strony wspierać imigrantów w procesie stawania się częścią społeczeństwa ${ }^{29}$.

\section{Grupy muzułmańskie w Niemczech}

Z przywoływanych już badań wynika, że zaledwie $22,2 \%$ sunnitów, $10,3 \%$ szyitów $^{30}, 10,2 \%$ alewitów, 28,5\% innych (np. ibadyci, ahmadijja) przyznaje się do członkostwa w religijnych organizacjach i stowarzyszeniach $^{31}$. To wskazuje na istnienie tzw. milczącej większości muzułmanów, czyli osób niezrzeszonych i nie reprezentowanych przez żadną $\mathrm{z}$ działających struktur. Oczywiście poziom zaangażowania w ich prace jest jeszcze niższy. Pomimo tego dość niskiego poziomu reprezentacji, podziały na różnego rodzaje związki i stowarzyszenia odzwierciedlają w pewnym stopniu różnorodność grup muzułmańskich w Niemczech. Przyjmując kryterium religijno-etniczne można wyróżnić następujące ugrupowania $^{32}$ :

a) turecko-sunnickie, w tym islam państwowy (DiTiB), islam polityczny (Milli Görüş), islam mistyczny czyli bractwa sufickie (głównie Nakszbandijja, Narşu, Fethullahci), islam nacjonalistyczny (np. tzw. Grauen Wölfen);

b) turecko-alewickie, w tym Föderation der Aleviten Gemeinden in Europa (AABF);

c) arabsko-muzułmańskie, w tym Islamische Gemeinschaft in Deutschland (IGD), Islamisches Zentrum Aachen (IZA), Zentralrat der Marokkaner in Deutschland,

29 Conclusions of the plenary held on 17 May 2010. Future work programme, Deutsche Islam Konferenz, www.deutsche-islam-konferenz.de, (28.09.2010).

30 Jeden $\mathrm{z}$ pierwszych sporów o to, kto ma sprawować władzę w młodej gminie muzułmańskiej po śmierci proroka Muhammada doprowadził do historycznego podziału na sunnitów i szyitów. Główna różnica pomiędzy sunnitami a szyitami zasadza się na ogromnym uznaniu dla Alego, kuzyna i zięcia Muhammada w przypadku szyitów. Pierwotnie polityczny spór zaczął nabierać mistycznego znaczenia po tragicznej śmierci Alego, a następnie jego synów Hasana i Husajna, którym przypisano szczególną siłę i rolę w gminie.

31 S.Haug, S. Müssig, A. Stichs, op. cit., s. 168-169.

32 Podział przyjęty za Friedrich Ebert Stiftung, http://www.fes.de/fulltext/ asfo/00803008.htm\#E10E7, (28.09.2010). 
d) szyickie, w tym Islamische Zentrum Hamburg; oraz Ahmadijja, np. Ahmadijja Muslim Jamaat Deutschland, ${ }^{33}$

e) bośniackie i albańskie, np. Islamische Gemeinschaft der Bosniaken in Deutschland (IGBD).

Trudno w tego rodzaju pracy omówić wszystkie grupy, z pewnością kilka z nich zasługują na szczególną uwagę z punktu widzenia roli odgrywanej $\mathrm{w}$ dwóch organizacjach wiodących lub uczestniczenia w bezpośrednich rozmowach z rządem.

\section{Grupy tureckie}

Najważniejszą organizacją wśród ludności pochodzenia tureckiego pod względem odczuwanej do niej przynależności stanowi DiTiB. Reprezentuje ona turecki islam państwowy wraz z zachowaniem zasady oddzielenia religii od państwa. Jest uznawana za jednego z najważniejszych partnerów do rozmów z państwem ${ }^{34}$.

Problem z DITíB polega głównie na jej ścisłej współpracy z Ankarą, by nie powiedzieć zależności od Prezydium d. s. Religii. Obecnie w kontekście liberalizowania zasad przyznawania obywatelstwa niemieckiego stanowi spore wyzwanie dla niezależności i suwerenności organizacji w Niemczech $^{35}$. $\mathrm{z}$ badań Zentrum für Türkeistudien wynika, że do DiтíB przynależność osobistą lub poprzez członków rodziny zgłasza aż 76,8\% badanych przedstawicieli ludności pochodzenia tureckiego, przy czym zaledwie $55 \%$ badanych określa się jako „raczej religijni”, a $28 \%$ „mocno religijni” ${ }^{36}$. Przynależność do określonego związku opiera się m.in. na od-

33 Jest to niewielka grupa, lecz bardzo zróżnicowana. Począwszy od podziału ze względu na ilość uznawanych imamów wyróżniamy najbardziej umiarkowanych zajdytów (wierzących w 5 imamów), ezoterycznych isma'ilitów (tzw. siedmiowców) z których wywodzi się znana sekta asasynów, oraz najbardziej rozpowszechnionych imamitów (tzw. dwunastowcy), Zob. M. M. Dziekan, Cywilizacja islamu..., s. 98. Wspomnieć należy także na inne rozróżnienie, na przedstawicieli odłamu szyizmu kwietystyczny i politycznego. Ten pierwszy, wysoce mistyczny i nie zajmujący się problemem władzy doczesnej odłam reprezentuje m.in. Ali As-Sistani. Drugi zajmuje bardzo wyraźne pozycje w kwestiach politycznych, co obserwować można we współczesnym Iranie i Iraku jako „mocno religijni”.

U. Spuller-Stageman, op. cit., s. 111.

P. Heine, op. cit., s. 122.

${ }^{36}$ Badania przeprowadzone zostały na grupie reprezentatywnej 1000 osób pochodzenia tureckiego mieszkających w Niemczech. Przynależność do związku często jest rozszerzana na całą rodzinę, jeśli choć jeden męski członek rodziny taką przynależność uznaje. Zob. F. Şen, M. Sauer, Islam in Deutschland. Einstellung der türkischstämmiger Muslime. Religiöse Praxis und organisatorische Vertretung türkischstämmiger Muslime 
wiedzaniu określonych meczetów, a DíTíB zarządza prawie $80 \%$ meczetów w Niemczech. W tym samym badaniu 52\% respondentów przyznało, że czuje się reprezentowani przez DiTiB, natomiast $3 \%$ uznało za swego reprezentanta Islamische Gemeinschaft Milli Görüş (Milli Görüş, IGMG), natomiast $2 \%$ wskazało Die Vereinigung der Aleviten-Gemeinden (AABF) ${ }^{37}$. Potwierdza to raport ministerstwa, z którego wynika, że najbardziej rozpoznawanym związkiem, bo przez $44 \%$ muzułmanów, jest DíTiB. Natomiast pozostałe organizacje rozpoznawane są przez muzułmanów niemieckich na poziomie: $27 \%$ - Zentralrat, $25 \%$ - VIKZ, $27 \%$ - $\mathrm{AABF}^{38}$.

Formacja popularnie określana po prostu Milli Görüş jest główną siłą w jednej z istniejących organizacji wiodących - Islamrat. Zalicza się do największych muzułmańskich organizacji działających w całej Europie i miała silne powiązania, także osobiste, z szefem partii Refah (Partii Dobrobytu) Neckemtinnem Erbakanem oraz z jego rodziną. To ugrupowanie reprezentujące turecki islam polityczny i kojarzone jest, jak już wspomniano, z radykalnym islamizmem. Badacze jednak zaobserwowali pewne zmiany w łonie organizacji i ruchu, które wskazują, że możemy mieć tu do czynienia nie z organizacją polityczną, która islam wykorzystuje wyłącznie do mobilizacji sił politycznych, a bardziej z ruchem religijnym $^{39}$ czy grupą nacisku.

Wpływ bractw sufickich wśród tureckich wyznawców islamu w Niemczech jest niezwykle istotny. Sufizm czyli mistycyzm muzułmański charakteryzuje się wielością bractw (określonych często niesłusznie muzułmańskimi zakonami), wiąże się to z przekonaniem sufickich mistyków, że do Boga prowadzi wiele dróg (arab. tarika) i każda jest dobra jeśli prowadzi do celu $^{40}$. Bractwa sufickie przenikają w sposób bardziej swobodny niż ortodoksyjny islam i są trudniejsze do zamknięcia w pewne ramy, ponieważ poziom instytucjonalizacji jest tutaj niewielki. Niektóre organizacje, czy jej twórcy nawiązują do pewnych interpretacji poszczególnych bractw, czy uczestniczą w popularnych recytacjach 99 świętych imion Boga. Zazwyczaj jednak uczestnictwo jest tutaj bardzo zindywidualizowane i odbywa się bardzo często w prywatnych domach i mieszkaniach $^{41}$. Abdullah Efendi, szacuje, że ok. $20 \%$ niemieckich muzułmanów

in Deutschland (Ergebnisse einer bundesweiten Befragung), Stiftung Zentrum für Türkeistudien, Essen 2006, s. 36.

Ibidem, s. 15.

S. Haug, S. Müssig, A. Stichs, op. cit., s. 173.

Ibidem, s. 121.

M. M. Dziekan, Cywilizacja islamu..., op. cit., s. 101.

U. Spuler-Stagemann, op. cit., s. 135. 
i min. 10-15\% muzułmanów pochodzenia tureckiego - należy do grup sufickich. Niektórzy sufizm określają mianem „nowej” religii młodych. Zwrócić należy jednak uwagę na istnienie oprócz sufickich porządków typu sunnickiego i szyickiego, trzecią kategorię bractw nie przynależących do tych tradycyjnych muzułmańskich porządków określanych także mianem Sufi, ale nie mających wiele wspólnego z islamem ${ }^{42}$.

Warta wspomnienia jest tutaj także die Islamische Gemeinschaft Jama'at Nur (Jama'at Nur), istniejąca w Niemczech już od 1967 roku. Do organizacji należy ok. 40 medres (szkół koranicznych), na czele których nie stoi imam ${ }^{43}$, przez co nie pełnią one funkcji meczetu ${ }^{44}$. Obok IGMG ten związek stanowi najważniejszą siłę w Islamrat. Organizacja ma na celu przede wszystkim dotrzeć do młodzieży z nowoczesnym przesłaniem pogodzenia wiary ze współczesnością. Jama’at stara się utrzymać dobry kontakt z innymi grupami muzułmańskimi, prowadząc tym samym politykę dialogu i współpracy.

Specyficznym ugrupowaniem, które zrzesza określoną grupę tureckiego pochodzenia jest Föderation der Aleviten Gemeinden in Europa (AABF). Alewici są grupą religijną wyodrębnioną w ramach szyickiego odłamu. Szacuje się, że około 15-20\% tureckich muzułmanów należy do wspólnoty alewickiej, która sama jest podzielona i będzie się różnić od grup alewickich z krajów arabskich ${ }^{45}$. Odrębność myśli alewickiej od sunnickiego islamu jest spora, dlatego organizacja już od jakiegoś czasu stara się o wprowadzenie odrębnych alewickich lekcji religii, oprócz lekcji islamu, który w dążeniu do spójności, wiele kwestii sprowadza do jednej wersji (najczęściej sunnickiej). Alewici uznani są za najmłodsze ugrupowanie szyickie i jednocześnie najbardziej prężne politycznie, szczególnie w Turcji. Wierzą w 12 imamów szyickich, ale łączą islam imamicki z elementami szamanizmu turkmeńskiego. Dość swobodnie podchodzą do obowiązku modlitwy oraz modlą się w domach zgromadzeń (cemevler), a nie w meczetach ${ }^{46}$.

Wspomniana wielokrotnie Islamrat, jest już w mniejszym stopniu niż DITIB reprezentantem społeczności tureckiej, ale nadal rozpoznawana jest jako głos tureckiego islamu. Oprócz dwóch już wymienionych organizacji biorą w jej pracach również udział także Dachverdband Bosnischer

\footnotetext{
Ibidem, s. 136.

${ }^{43} \mathrm{~W}$ tym rozumieniu imam oznacza przewodnika w modlitwie, wygłaszającego kazanie piątkowe (arab. chutbę), a nie jak u szyitów odkupiciela czy następcę proroka.

F. Şen, M. Sauer, op. cit., s. 10.

F. Şen, H. Aydin, Islam in Deutschland, Verlag C.H. Beck, Monachium 2002, s. 20.

J, Danecki, Podstawowe wiadomości o islamie, t. 1, Dialog, Warszawa 2002, 336-337.
} 
Gemeinschaften oraz Islamische Weltkongress (apT) Deutschland oraz 7 różnych związków regionalnych związków muzułmańskich w stolicach regionów.

\section{Nietureckie organizacje muzułmańskie}

Za bardziej wielokulturową i różnorodną etnicznie z dwóch muzułmańskich organizacji wiodących należałoby uznać Zentralrat ${ }^{47}$. W jej skład wchodzą m.in. organizacje uznane za ośrodki radykalnych interpretacji islamu, nawiązującego do prac Abu Ala Maududiego i egipskiej gałęzi Braci Muzułmanów, która zaaprobowała pewne elementy myśli politycznej Maududiego, jak dżahilijja świata zachodniego oraz interpretacja dżihadu rozumianego jako walka zbrojna $z$ niewiernymi ${ }^{48}$. Jest to jeden z najbardziej ekstremistycznych rodzajów fundamentalizmu muzułmańskiego. Między innymi Islamischen Zentrum Aachen wiąże się z takimi kierunkami i nurtami w myśli muzułmańskiej ${ }^{49}$. Zenralrat powstała w wyniku odłączenie się od Islamrat ${ }^{50}$.

Szyici w Niemczech reprezentowani są głównie przez dwie instytucje, Islamische Zentrum in Hamburg z silnymi wpływami Iranu od czasów rewolucji '78 roku. Oprócz szyitów irańskich w Niemczech mamy do czynienia z szyitami tureckimi, zazwyczaj „dwunastowcami” ${ }^{\text {51 }}$. Kolejną grupą w ramach tej wspólnoty jest ahmadijja, nurt reformatorski, których przedstawiciele w Niemczech pochodzą głównie z Pakistanu. Przykładem organizacji tego nurtu i reprezentantem dla 30 tyś. mieszkańców, jak sama twierdzi, jest der Ahmadiyya Muslim Jamaat ${ }^{52}$. Ahmadijja powstała pod koniec XIX w. w Indiach, a twórcą jej był Mirza Gulam Ahmad, „który stwierdził, że spłynęło na niego Boskie objawienie i że on sam jest prorokiem" ${ }^{23}$. Ahmadijja podobnie jak alewici i inne reformistyczne ruchy

P. Heine, op. cit., s. 131.

48 Dżahilijja świata zachodniego jest stanem nawiązującym do okresu zacofanie plemion arabskich przed islamem, ale przeniesiona do realiów współczesnych pełni funkcję swoistego uzasadnienia prowadzenie działań zbrojnych (dżihadu) przeciwko Zachodowi, który podobnie jak w czasach dżahilijji plemiona arabskie potrzebują oświecenia w postaci islamu. Zob. A. Mrozek-Dumanowska, Wspótczesny ruch odnowy islamu. W poszukiwaniu własnej tożsamości kulturowej, Prace Monograficzne Zakładu Krajów Pozaeuropejskich Polskiej Akademii Nauk, Warszawa 2000, s. 25.

P. Heine, op. cit., s. 129-131.

U. Spuller-Stagemann, op. cit., s. 113.

A. S. Nalborczyk, op. cit., s. 337.

Więcej na oficjalnej stronie organizacji: http://www.ahmadiyya.de.

J. Danecki, Podstawowe wiadomości o islamie, t. 2, Dialog, Warszawa 2002, s. 107. 
powstały na gruncie islamu są zwalczane przez niektóre ugrupowania muzułmańskie. Tymczasem ahmadijja w sposób purytański odnosi się do źródeł islamu, czyli Koranu i Sunny, rygorystycznie przestrzega wszystkich zasad i obowiązków muzułmanina, ale uważa się za przedstawicieli szkoły hanafickiej ${ }^{54}$, najbardziej umiarkowanej szkoły prawnej sunnitów.

Ten przegląd wybranych grup nie wyczerpuje w żadnym razie tematu społeczności muzułmańskiej w Niemczech i nie takie było też jego zamierzenie. Bardziej istotne $\mathrm{w}$ kontekście tego artykułu było pokazanie pewnej dynamiki i złożoności podziałów, a co za tym idzie różne źródła i konteksty przynależności czy identyfikacji z poszczególnymi grupami czy też muzułmanami jako wspólnotą. Nowe otoczenie i środowisko prawne stawia przez niemieckimi muzułmanami i ich instytucjami wyzwanie skoordynowania już istniejących i tworzących się struktur. Zauważone podziały i różnice wyniesione z krajów pochodzenia lub/i odmiennych praktyk religijnych mogą być pewnym punktem wyjścia do rozmów i uzgadniania nowego wspólnego podejścia. Ignorowane i spychane w cień mogą przeszkadzać i blokować porozumienie. Jednocześnie warto się zastanowić, na ile przedstawione różnice są wyrazem, jak już było tu wspomniane, europejskiego racjonalizmu, a na ile dostrzec należy ponad nimi jednością, podkreślaną przez niektóre grupy.

W kontekście tej różnorodności nie dziwią pomysły o zaakceptowaniu przez rząd niemiecki więcej niż jednego instytucjonalnego reprezentanta wspólnot muzułmańskich, w ten sposób otwierając drogę islamu do działania oficjalnym obiegu prawnym na tych samych prawach jak wspólnoty katolickiej, czy protestanckiej. Istnienie i dotychczasowe działanie DIK pokazuje, że administracja zdaje sobie sprawę z tego zróżnicowania, choć można by to zinterpretować także jako sposób na radzenie sobie $\mathrm{z}$ radykalizmem przez faworyzowanie bardziej umiarkowanych choć słabiej wyemancypowanych grup.

Wyniki badań pokazujące, że największym problemem nie jest integracja społeczna, a korelacja separatyzmu społecznego i islamu nie jest tak oczywista jak można by się tego spodziewać, wskazują pewne nowe możliwe kierunki działania państwa. Jednym z nich jest na pewno współpraca na rzecz wzmocnienia integracji lingwistycznej i podniesienie poziomu edukacji wśród niektórych grup muzułmańskich. Wprowadzenie na trzy niemieckie uniwersytety kształcenia imamów jest też jasnym sygnałem, w którym zmierza niemiecka polityka integracyjna.

54 Ibidem, s. 109. 
Swoistym i trudnym do opanowania zjawiskiem jest z pewnością wzrost tendencji islamofobicznych, którego przejawem jest chociażby rosnąca popularność poglądów podobnych do Thilo Sarrazina, twierdzącego między innymi, ze muzułmanie są obciążeni genetycznym lenistwem i niższą inteligencją ${ }^{55}$. Twórca tych stwierdzeń został już zwolniony ze swych funkcji publicznych, jak zasiadanie w Zarządzie Bundesbanku, lecz nie zmienia to faktu, że duża część społeczeństwa niemieckiego sympatyzuje z takimi poglądami, a jak można dowiedzieć się z raportu Open Society $^{56}$, islamofobia w przeciwieństwie do rasizmu i ksenofobii stała się wręcz akceptowalna społecznie w pewnych kręgach tradycyjnie tolerancyjnych i otwartych na inność.

W obliczu takich wyzwań z pewnością relacja państwo niemieckie muzułmanie rozwijać się będzie dynamicznie, choć możliwe, że gdzieś na granicy wspólnoty muzułmańskiej, skoro czterech głównych partnerów do rozmów z rządem jest rozpoznaniych przez max. 30\% całej społeczności muzułmańskiej. Jednocześnie dwie organizacje wiodące, pretendujące do miana reprezentanta wspólnoty, nie bierze obecnie aktywnego udziału w pracach muzułmańsko-rządowej platformy jaką jest DIK.

Proces w kierunku wprowadzania islamu do oficjalnego obiegu politycznego można uznać jednak za rozpoczęty. Zarówno ze strony państwa, poprzez dostrzegania potencjalnego podmiotu politycznego, jak i ze strony części muzułmańskiej wspólnoty pracującej nad podniesieniem swej pozycji w obiegu politycznym. Przykładem są tutaj zmiany w zasadach nadawania obywatelstwa, przebudowa struktury DIK oraz rozpoczęcie projektów z tą częścią muzułmanów, która jest do tego gotowa wskazuje na determinację administracji niemieckiej. Z drugiej strony są to usilne próby konsolidacji czynione przez główne organizacje oraz próby wywierania nacisku.

A N N A PALUSZEK

55 P. Buras, Czego się boją Niemcy? Spór o antymuzutmańską książką Sarrazina, [w:] Gazeta Wyborcza, 17.09.2010, http://wyborcza.pl/1,76498,8361520,Czego_boja_sie_Niemcy__ Spor_o_antymuzulmanska_ksiazke.html, (29.09.2010).

56 Tłumaczenie wyjątków raportu „The Muslims in Berlin" w niniejszym tomie „DP”, raport dostępny: http://www.soros.org/initiatives/home/articles_publications/ publications/berlin-muslims-report-20100427. 


\section{Abstract}

The goal of this article is primarily to present modern challenges of Muslim community in Germany and their diversity and interdependence with the modern trends of Islamic social and political thought.

Muslims in Germany are a young and very diverse community in terms of ethnic, social and religious, but still Turks are predominant population. On the one hand, German Muslims are the descendants of temporary workers, who came mainly from Turkey, Morocco, Tunisia and former Yugoslavia. On the other hands this community has its origins in political exile and refugee from Palestine, Afghanistan, Bosnia, Egypt, Iraq or Iran. According to this we can see among this community formal and less formal links with external centers such as Iran, Turkey and Saudi Arabia, which has the impact on different groups and also on the level of integration of this community with German society.

In the context of religious diversity in Germany, we distinguish groups such as Sunnis (majority), small group of Shia mostly from Iran and some members of the Ahmadiyya Muslim Community from Pakistan and Alevis.

Recent research of the Ministry of the Interior suggest that in Germany there are about 4 million Muslims, not as it was estimated previous about 3 million. The results of this study also show that the correlation between the confession of Islam and the integration is not so obvious. Simultaneously, the public law about religious community in Germany enforces a high level of institutionalization of Islam. Since the early 80 's, along with the second generation Muslim immigrants educated in German schools, reinforcing the tendency to organizing. After this process Islam has become a visible religion in Germany.

Most recognized organization are Türkisch-Islamische Union der Anstalt für Religion e. V. (DIтіB) through $44 \%$ of Muslims researched in 2009, then are specified Zentralrat der Muslime in Deutschland by $27 \%$ repospondents, Verband der Islamischen Kulturzentren - 25\% and Alevitische Gemeinde Deutschland $27 \%$. Although there are many different organizations and associations we can still describe Muslim Community in German as a community at a low level of institutionalization.

We can observe also a process of the social integration of Muslim and some effects of the integration policy conducted by the German government but sill we can find as well some examples of the Islamophobia in German Society. 